\title{
The Chequered History of the Prodigal 'you' Pronoun
}

\author{
Dennis Michael Bryant (Corresponding author) \\ Faculty of Arts, University of Canberra \\ 11 Kirinari Street, BRUCE, Australian Capital Territory, Canberra, 2617. Australia
}

Tel: 61-04-0049-9265Ｅ-mail: DrDennisBryant@gmail.com

$\begin{array}{ccc}\text { Received: January 25, } 2021 & \text { Accepted: February 21, } 2021 \quad \text { Published: March 8, } 2021 \\ \text { doi:10.5296/ijch.v8i1.18271 } & \text { URL: https://doi.org/10.5296/ijch.v8i1.18271 }\end{array}$

\begin{abstract}
This paper pursues the proposition that today's English can be likened to a spectacularly-coloured butterfly that is always prepared to flutter forward undaunted by its dazzling change over time. In order to exemplify change as a long-term characteristic of English, this paper charts the progress of the second person 'you' pronoun, from Old English days, through to Middle English times, arriving into Modern English where the 'you' pronoun displays seemingly prodigal behaviour having abandoned its richness of case forms, resulting in a single form now representing all cases while also indicating both a multiple person audience while equally interpreted to indicate a singular person audience. However, it is clear that the latter behaviour is at odds with ' $y o u$ ' requiring a grammatically plural verbal particle. Such a paradox may leave ESL, and even native speakers, with an unfavourable impression that 'you' has to be accepted as an un-analysable concept. Given existing claims of lethargy in correctly informing the Academy on a range of English Grammar topics, this paper seeks to follow a Critical Theory methodology of evidence-based analysis of the 'you' situation; that is, this analysis consults Old English texts through to Middle English texts to today's English usage, always providing supporting examples along the way.
\end{abstract}

Keywords: ESL educational practice, ESL curriculum redevelopment, ESL teaching, second language acquisition

\section{Introduction}

Today's ESL teachers face a critical shortage of carefully analysed, grammatical descriptions of English. This situation exists today because past "grammarians" have been unsystematic in their analyses and hence their commentaries have suffered accordingly. The only approach that is reliable is one in which careful analysis dominates a critical approach. Nowhere is a failure to analyse more lamentable than with the second-person pronoun where treatment is 
trivial. But perhaps more telling are cases where second-person pronoun treatment is eschewed altogether. This paper begins a meaningful discussion by embracing a systematic approach that starts with Old English, modestly moving onto Middle English, and finally onto today's Modern English. This guided approach should inform ESL teachers who may think of English as unpredictable in its usage of second-person pronouns. In fact, English is always systematic in its willingness to sacrifice conventional constraints in order to maximise operational flexibility, and this feature of English has been demonstrated in recently published papers, which treat a constellation of scenarios. Now that same operational flexibility is being noted herein as applying additionally to the second-person pronoun in today's English. It is time for the Academy to provide informative, well-analysed metadata for ESL teacher edification that will hopefully supersede the present ever-slumbering Rip Van Winkle-like works of imagined grammatical reality. Each ESL student deserves to learn from a grammar that has been informed by critical analysis, with each student then benefitting by constructing a mental perception, or more lyrically 'a coat-hanger in the mind' which services rapid but correct English communication. Stated according to learning theory, a part of this paper's motivation is a belief that this paper could be congruous with assisting student learning autonomy, as espoused by Benson.

In recent analyses of English Grammar, Bryant argues in favour of the proposition that English Grammarians have lost their way. 'Lost their way' is defined as ignoring a willingness to undertake intellectual inquiry in a manner that would conform to Critical Thinking theory. Continuing a tradition of exemplifying critically-analysed English Grammar, this paper treats the second person pronoun ' $y o u$ '. Over the course of time, the second person 'you' pronoun has undergone dazzling change. Simplification has been the guiding theme of its dazzling change. However, the outcome of simplification does result in paucity, such that only a single form remains in today's English. Paucity is defined as frugally using one form to function unchanged in multiple roles; these being, as a nominative (which is sometimes described as an Subject); as an accusative (or, Object), but also as a dative (or, Indirect Object). By way of a brief explanation, in today's English, pronoun position within a declarative sentence determines a pronoun's function. To exemplify further using Greenberg's Subject-Verb-Object (SVO) terminology, nominative indicates an actor role with placement in a Subject position; while placement in an Object position indicates an accusative role (that is, someone or something being acted upon); else it may indicate a dative role, again within the Object position. However, before continuing with pronouns, there is caveat to be made here briefly. This paper contends that similar-in-form yet dissimilar-in-function, 'your' and 'yours', are not the major focus of this paper on the grounds that these so-called 'possessive pronouns' serve primarily as adjectives, not as pronouns.

An interest in 'you' is warranted because of the irony, and perhaps confusing situation for ESL speakers in that 'you' appears to be a non-plural form, yet it requires a grammatically plural 'are' particle. In grammatical terms, 'you' does not carry an indication of number. For example, 'you' does not signify whether it is referring to a single listener, or to multiple listeners. Gunn \& Eagleson lament this situation, noting ruefully that in today's English one vernacular accepts 'youse' as an indication of plurality as it simulates standard English 
formation of plurality. However, Gunn \& Eagleson do point out that 'you-all' as well as 'you-lot' are equivalents, which might be reflected in current usage, like 'you-guys'. Clearly conscious of this requirement, yet daunted neither by frugality of form, nor by judgmental grammatical dictates, many native-speakers appear to have decided that they are also free to interpret its function as identifying a singular topic. However, English was not always frugal in forms, especially as regards Old English, which is also referred to by Sapir as Anglo-Saxon English.

\section{The Richness of Old English (OE)}

Surprising as it might be, the English language was not always known for its paucity; quite the contrary. Mitchell notes that OE possessed three impressive sets of pronouns, covering not only singularity and plurality nominative and accusative as well as dative cases, but also a dual pronoun to communicate two listeners; that is, a dual pronoun case for nominative and other cases. In fact, Old English catered for a total of twelve pronouns. However, when describing OE, position was not synonymous with a pronoun's function. In lieu, function was determined by a pronoun's form and not its position. The forms and functions were called 'cases' or 'inflections'.

The OE forms were 'thou, thee, thee' which functioned to indicate 'you' respectively nominative, accusative and dative function - but with regard to number these indicated only a singular 'you'. Notably, there is a re-use of 'thee' to indicate both accusative and dative function. This re-use is understandable for the reason that there is economy in using a single form for two functions, especially with a large fleet of pronouns. Additionally, stress and context can often be relied upon as important arbiters of meaning.

Although absent today, the OE dual pronouns were 'yit, inc, inc' meaning 'you-two' (nominative, accusative and dative function respectively). In a further display of economy, the 'you-two' 'inc' form is re-used to indicate both accusative and dative function; corresponding to the earlier-mentioned 'thee, thee' forms for singularity. By way of an explanation concerning 'yit' spelling, Mitchell overwhelmingly prefers to use 'git' spelling across the vastness of his scholastic discussions, but later recants by stating that the leading ' $\mathrm{g}$ ' character was pronounced as a soft ' $y$ ' sound! This paper has accepted that interpretation. Having witnessed two instances of frugality, so far, it would be a reasonable expectation that today's English is likely to have inherited this frugality gene. As regards plural number, re-use and frugality continues with the 'yee, eow, eow' forms used to express several referents; that is, 'yee' for 'you-several' nominative and, 'eow' to identify the two non-nominative forms of 'you-several' which function as both accusative and dative cases.

Knowing that OE pronouns used case endings, would it be the sheer volume of cased pronouns or would it be the case concept itself that intrigues modern day speakers? It could well be the sheer volume of cased pronouns that is intriguing. Today's Modern English speakers have inherited and are presently users of, but perhaps unwitting users of, case. It is an intriguing twist that today's pronoun system still features case marking, albeit a fractured twist. For example, it would be inconceivable for a native speaker to mix up the use of accusative with nominative, such as 'me, I; her, she; him, he; them, they'. The twist is that 
English has changed to a positional system, so speakers no longer identify, say, 'them, they' as case forms indicative of different grammatical function; instead they equate these to be Object, Subject position and role. Clearly, there was a time of 'sweeping change', which Wrenn refers to as a 'period of lost inflections' meaning that position became the new indicator of pronoun function, overtaking case marking awareness. Although position now indicates function, their residual redundancy forms may indeed act as a secondary confirmation, and within rapid communication scenarios a small amount of redundancy may be an asset.

While the above paragraphs were a brief incursion into Old English pronouns, it was not only an opportunity to demonstrate that $\mathrm{OE}$ used the 'inc' pronoun to perform in two roles with no change in shape - but it was also an opportunity to mention that widespread repackaging, to achieve operational flexibility, is a feature that is very much alive in today's English. Although dual pronouns have been lost, but with respect to today's second person pronoun usage, English maintains its tradition of active re-use as evidenced in an unchanged 'you' in multiple roles, these being nominative and accusative as well as dative. If there is a thread of continuity to be seen to link OE with today's English, it is that an unchanged 'you' pronoun form is still re-used in multiple roles. Therefore, it is evident that OE was at ease in deploying a pronoun that was indistinguishable in shape yet differed in function. One might be tempted to conclude that $\mathrm{OE}$ reuse was an instance of contradiction or, restated, an inability to have faith in a fully distinguishing case system. On the other hand, one may choose to conclude that reuse was an indication of common sense by avoiding OE speaker overload.

While some OE heritage has been lost, there is an important feature of OE which remains alive and well today; and that is our gender heritage. OE had three gender forms but these forms were available in third person pronouns only. As an example, and considering only singular number, these were 'hee, heeo, hit' (being masculine, feminine and neuter) for 'he, she, it' nominative case. Two of these forms appear to have come through almost unscathed as today's English 'he, it'; while the feminine 'heeo' seems to have acquired a slightly different form, with small sound changes at each of its extremities - the initial single ' $h$ ' sound has morphed into the digraph yet single 'sh' sound, while the trailing 'o' sound has been dropped. For those believing themselves to be unfamiliar with the concept of sound change over time, it is well to recall to mind today's pronunciation of words like 'through, borough'. Perhaps more convincing are the pronunciations of short strings like 'would have' to become 'would-a' in speech. Additionally, in some dialects of today's English, there is a tendency to pronounce ' $t$ ' as ' $d$ ' under some circumstances, such as in 'impor-d-ant' for 'important'; also, 'bought' for 'b-r-ought'.

\section{Old English Examples}

OE, which is known also as Anglo-Saxon English, was a time of Angles, Saxons and Jute invasion into a Brythonic-speaking England, from Europe. In time, four dialects were to develop, these being Northumbrian, Mercian, Kentish and West-Saxon. Alfred King of the West-Saxons from 871-899 A.D., expressing himself in West-Saxon dialect, wrote the following: 
'Englisc [is] thaet ('that') gethiode ('language') the ('which' as an indeclinable relative pronoun representing 'which, who, to whom, whose'for all cases and numbers) we ('we'first, plural, nominative) ealle ('all') ge-cnaw-an ('know', with a prefix and a suffix) maegen ('can').

With explanations removed, it becomes, simply:

'English [is] the tongue that we can all understand'.

As a final example of OE, but structured as an OE poem, consider the following extract. It is taken from 'The Husband's Message', in which a loving husband who is seeking to be reunited with his estranged wife, sends her a message. The intermediary delivering the message states that Wife should be assured that Husband would keep the vow. Elucidating on the vow, the intermediary elaborated 'which 'you-two' had exchanged in bygone days'.

In OE, this vow is:

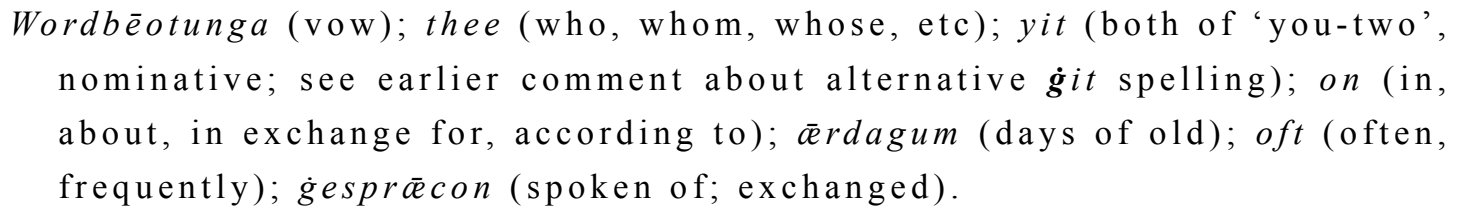

Delivered with a more poetical bent, this could be recast as: 'The oaths which 'you-two' lovers swore so long ago'.

\section{A Transition to Middle English (ME) Paucity}

While Old English needed a wealth of inflections to identify number (dual, singular and plurality) across cases (nominative, accusative and dative), such a wealth of 'you' forms was not sustained into ME. For example, in an Introduction to Geoffrey Chaucer's 'The Canterbury Tales', which was written towards the close of the fourteenth century, Cook makes no mention of $\mathrm{OE}$ dual number, meaning that nominative 'yit' and accusative-cum-dative 'inc' did not carry across to ME. Therefore it is reasonable to say that the loss of dual number has been with speakers for a long time. But perhaps today's speakers have been innovative in creating their own 'you-two' equivalents?

Continuing with number, but moving to singular, Cook's listing of ME pronouns shows that 'thou, thou, thee' came across unscathed. Cook adds that these forms 'were usually confined to familiar use between intimates or to inferiors' [p. xxiii]; presumably not to superiors.

\subsection{Middle English Examples}

Pronoun usage in ME times can be seen in the late fourteenth century story 'The Canterbury Tales' by Geoffrey Chaucer, where the Host accuses the Miller of being in a drunken state and witless:

Thou art a fool; thy wit is overcome.

Ongoing usage of pronouns in ME times can be seen also in Shakespeare's fifteenth century 
play 'The Tempest' where Caliban has no hesitation uttering in Act IV, Scene I:

See thou here? / Thine own forever, and I, thy Caliban.

Although it may have been in decline, such usage persisted into nineteenth century literature and can be seen, for example, in Robert Louis Stevenson's 'Prayer' poem:

My heart is evil in Thy sight: My good thoughts flee: / O Lord, I cannot wish aright - Wish you Thou for me.

Similarly, in Keat's well-read poem, 'Ode on a Grecian Urn'.

Thou still unravish'd bride of quietness, / Thou foster-child of silence and slow time.

\section{A Transition to Today's Modern English Paucity}

In today's English, the trend to pronoun paucity has continued, with the demise of the more personal forms 'thou, thee, thee'. In Wrenn's lament, 'you performs the functions of 'thou' and 'thee' as well as 'ye', leaving the Middle English plural form 'you' as the victor in the last round of the battle for survival. Although 'you' lacks a visual indication of plurality, this is hardly surprising since its origins were in $\mathrm{OE}$ and the $\mathrm{ME}$ cases. Nevertheless, confirmation of plurality can be seen in its grammatical function of requiring plural article agreements, seen for example in 'you are, have, were'. In what may be seen as a mild rejection of paucity, there is of course the emergence of a plural form, 'youse', as well as other equivalents such as 'you-all', 'you-two'. This is not to say that equivalents enjoy a range of acceptance and operation that is unlimited.

To finalise this section, it would be remiss to not mention the dative concept. While OE had dative pronouns, today's English does not have a separate dative form of pronoun. Typically, dative may be defined as a need that arises in sentences that contain verbs like 'give, donate' which require a direct object as well as an indirect object. In this circumstance, instead of needing another form of pronoun, English supports the insertion of 'to' ahead of a pronoun (or noun) form, as in 'They will give money to 'you'. However, English supports a shortened but rearranged construction, as in 'They will give 'you' money' which Bryant discusses as 'indirect object promotion' as one instance of the Focus-promotion theory, which results in 'to' loss.

\section{Supporting a Claim of Prodigal}

With respect to the 'you' situation as described herein, a question must be asked: is it a valid choice to regard English as prodigal because of its frugality in having merely one form for which there are three functions? Perhaps some support for this paper's prodigal claim can be affirmed if a comparison were to be made with languages which do not exhibit frugality with regard to 'you'. For example, Thai has at least three forms of 'you', these being for polite yet informal usage; for respectful usage; and, for adults in addressing children; while Daud \& Omar note that Malay offers seven forms, which is an observation confirmed by Lewis. The linguistic wealth of these languages would suggest English, when judged by frugality, can be 
viewed as prodigal. Furthermore, and again supporting a case of referring to today's 'you' as prodigal, is the frugality of the 'you' form when compared to the wealth of her sibling pronouns. For example, differentiation of function, by form, is found with first person pronouns ('I, me'; 'we, us'); as well as with almost all third person pronouns ('he, him; she, her; they, them').

\section{Conclusion}

This paper explored the idea that English can be regarded as frugal in that it has only a single second person form 'you' which is obliged to undertake three functions, these being nominative, accusative and dative. On the other hand, this frugality could be seen as efficient - yet, it must also be seen to be prodigal in that posterity has suffered an extreme loss of a wealth of forms, an occurrence which has weakened the power of speech, giving rise to compensatory speech such as 'youse, youse-two, youse-all, youse-lot' and similar constructions. In a sense, this paper resolves an enigma to native speakers. That enigma concerns grammatical number as it refers to the second person 'you' pronoun, which can be used to address a multi-person audience. Supporting such usage is the fact that 'you' requires a grammatical plural 'are' particle. An unchanged 'you' can also be employed to address a singular audience based on the proposition of its not carrying a plural forming 's' suffix, but more so on speaker-need to address singular number. This paper's methodology resolved the enigma by tracing the history of third person from dual, singular, and plural cases in Old English; through to its Middle English heritage of forms; thence into today's accepted singular-looking form. Another part of the methodology was to provide exemplar text from each of the three historic divisions of English. Part of the impetus for undertaking this paper was the author's belief in the communicative validity of some of today's speakers who have chosen to rely on 'youse' to address a several-person audience. The other impetus was to provide a solid and reliable background to ESL teachers, who otherwise may need to delve into research themselves. Hopefully, the present research findings will function to assist ESL teachers and contribute to student Learning success.

\section{References}

Benson, P. (2001). Teaching and researching autonomy in language learning. New York: Longman.

Bolinger, D. (1968). Aspects of Language. New York: Harcourt, Brace \& World, Inc.

Briggs, H. (1951). Complete Poetry and Selected Prose of Keats. New York: The Modern Library.

Bruner, J. (1978). The role of dialogue in language acquisition. In A. Sinclair, R., J. Jarvelle, \& W. J. M. Levelt (Eds.), The Child's Concept of Language. New York: Springer-Verlag.

Bryant, D. M. (2019a). Focussing on Promotion in English Sentences to Inform ESL Educational Practice. Language, Literature and Culture, 2(3), 102-107. https://doi.org/10.5296/ijch.v6i2.15892

Bryant, D. M. (2019b). Focussing on Building up ESL Perception of Verbal Slot Complexity 
to Inform Educational Practice. Language, Literature and Culture, 2(3), 127-132.

Bryant, D. M. (2019c). Focussing on Decoding Contractions in English Sentences to Inform Educational Practice. International Journal of Culture and History, 6(2), 90-101. https://doi.org/10.5296/ijch.v6i2.15892

Bryant, D. M. (2020a). The Form and the Function that Defines and Associates Definite and Indefinite Articles in English Grammar. International Journal of Culture and History, 7(1), 30-40. https://doi.org/10.5296/ijch.v7i1.17213

Bryant, D. M. (2020b). Pursuing the Energetic yet Enigmatic Particle that Powers English Communication. International Journal of Culture and History, 7(2), 38-46. https://doi.org/10.5296/ijch.v7i2.17488

Bryant, D. M. (2020c). Focussing on Revealing English Grammar's Conceptual Unity amidst its Operational Diversity. Language, Literature and Culture, 3(2), 8-14.

Cook, S. (1961). The Canterbury Tales of Geoffrey Chaucer (2nd. ed.). Doubleday \& Company Inc, New York: Anchor Books.

Daud, M., \& Omar, A. (1973). Kamus Pelajar. Federal Publications Sdn Bhd, Kuala Lumpur.

Greenberg, J. H. (1973). Some Universals of Grammar with Particular Reference to the Order of Meaningful Elements. In J. H. Greenberg (Ed.), Universals of Language (pp. 73-113). London: MIT Press.

Gunn, J. S., \& Eagleson, R. D. (1966). Survey of Language. Sydney: Angus \& Robertson.

Hamby, B. (2015). Willingness to Inquire: The Cardinal Critical Thinking Virtue. In M. Davies, \& R. Barnett (Eds.), The Palgrave Handbook of Critical Thinking in Higher Education (pp. 77-88). New York: Palgrave MacMillan. https://doi.org/10.1057/9781137378057_5

Langacker, R. W. (1973). Language and its Structure: some fundamental linguistic concepts (2nd ed.). New York: Harcourt Brace Jovanovic, Inc.

Langbaum, R. (1964). “The Tempest” by William Shakespeare. New York: Signet Classics.

Lewis, M. B. (1972). Teach 'you’ Malay (2nd ed.). The English Universities Press.

Mitchell, B. (1995). An Invitation to Old English and Anglo-Saxon England. Oxford: Blackwell Publishers Ltd.

Potter, S. (1950). Our Language (2nd. ed.). Harmondsworth, Middlesex: Penguin Books.

Robertson, R. G. (1980). Robertson's practical English-Thai Dictionary. Japan: Charles E. Tuttle Co., Inc.

Sapir, E. (1921). Language: An Introduction to the Study of Speech. New York: Harcourt, Brace \& World, Inc.

Stevenson, R. L. (2021). 'Prayer', excerpt extracted on the tenth of January 2021, from the 
internet site Poemist.com.

Vardi, I. (2015). The relationship between Self-Regulation, Personal Epistimology, and Becoming a "Critical Thinker": Implications for Pedagogy. In M. Davies, \& R. Barnett (Eds.), The Palgrave Handbook of Critical Thinking in Higher Education (pp. 197-212). New York: Palgrave MacMillan. https://doi.org/10.1057/9781137378057_13

Wrenn, C. L. (1949). The English Language. London: Methuen \& Co. Ltd.

\section{Copyrights}

Copyright for this article is retained by the author(s), with first publication rights granted to the journal.

This is an open-access article distributed under the terms and conditions of the Creative Commons Attribution license (http://creativecommons.org/licenses/by/4.0/) 